\section{Lunch quality and sociodemographic conditions between Brazilian regions}

\section{Qualidade do almoço e condições sociodemográficas entre as macrorregiões brasileiras}

\section{Calidad del almuerzo y condiciones sociodemográficas entre regiones brasileñas}

Bartira Mendes Gorgulho 1

Roberta de Oliveira Santos 1

Juliana A. Teixeira 1

Valeria T. Baltar 2

Dirce Maria Marchioni 1

\begin{abstract}
The objective of this study was to assess the quality of lunch consumed by adults in Brazil and its sociodemographic determinants in each Brazilian region. A cross-sectional study was carried out and a representative sample of regional populations was used. The sample comprised of 16,096 adults from the Brazilian National Dietary Survey, part of the Brazilian Household Budget Survey (POF). The lunch quality was evaluated by applying the main meal quality index (MMQI), comprised of 10 items of equal weights that resulted in a score that ranged from zero to 100 points. Linear regression models measured the association between lunch quality and sociodemographic factors. The average energy consumption at lunch was 704Kcal $(S D=300)$, and the meal quality score mean was 57 points $(S E=0.30)$. The North Region had the worst MMQI score (56 points, SE =0.07), while the Central had the best MMQI adjusted score (59 points, SE =0.05). The MMQI final score was positively associated with male gender and ages between 20-39 years, and was inversely associated with having eight years or more of education, per capita income of at least three minimum wages, and with the consumption of meals prepared away from home. Despite differences among sociodemographic factors, all Brazilian regions had a lunch composed of foods rich in sugars and fats, with insufficient portions of fruits and vegetables, resulting in a low meal quality.
\end{abstract}

Lunch; Feeding Behavior; Meals; Demographic Indicators

\author{
Correspondence \\ B. M. Gorgulho \\ Faculdade de Saúde Pública, Universidade de São Paulo. \\ Av. Dr. Arnaldo 715, São Paulo, SP 01246-904, Brasil. \\ bartira.gorgulho@gmail.com \\ 1 Faculdade de Saúde Pública, Universidade de São Paulo, São \\ Paulo, Brasil. \\ 2 Instituto de Saúde Coletiva, Universidade Federal Fluminense, \\ Niterói, Brasil.
}




\section{Introduction}

Meal consumption is part of a structured event that follows food combination rules. Analyzing such combinations allows us to understand the complexity and unpredictability of the diet, emphasizing peculiarities that would not be found in global dietary analyses 1,2,3,4,5,6,7,8. Furthermore, changes in the composition of a specific meal may be enough to change the postprandial and inflammatory response 5 .

In this way, to define an event as a meal, different aspects should be considered, such as time, energy contribution, social interaction and the number of foods combined 1,2,3,4,5,6,7,8. Breakfast, lunch and dinner, for example, although usual in several countries, may present different structures and meanings 3 . Dinner is considered the main meal for some countries, such as Great Britain, while in Brazil this is lunch 3,9 .

Brazil is a country with continental dimensions and great regional diversity ${ }^{10}$. There are important sociodemographic and economic disparities between the five macro-regions that, being associated with different food habits, influence incidences of diseases and mortality patterns. The poorer the educational level, the higher the prevalence of chronic diseases ${ }^{11}$. In this context, the geographic regions print their food identity. For example, in the North region more manioc flour, açai and fresh fish are consumed; in the Northeast more eggs and crackers; in the Central more rice, beans, beef and milk; in the Southeast and South more salt, bread, pasta, potatoes, cheese, yogurt and soft drinks 12.

Thus, considering differences in sociodemographic characteristics and food habits between the North, Northeast, South, Southeast and Central of Brazil, this study aims to evaluate the quality of lunch, the Brazilian main meal, consumed by adults and its demographic and socioeconomic determinants in each Brazilian region.

\section{Methods}

\section{Study design}

This study used individual food consumption data from the Brazilian National Dietary Survey (INA), composed of the personal food consumption block (questionnaire P07) of the Brazilian Household Budget Survey (POF) conducted in 2008 and 2009 by the Brazilian Institute of Geography and Statistics (IBGE) ${ }^{12}$. The project was approved by the Ethics Research Committee of the University where the study was developed.

\section{Participants and recruitment}

A sampling of POF 2008/2009, representative of Brazil, was carried out by clusters in two stages. Census tracts, the primary sampling units were selected by simple random sampling, and the permanent households, the secondary sampling units selected by simple random sampling without replacement within each census tract.

The size of the complete sample of POF 2008/2009 was 4,696 census tracts, with 59,548 selected households, yet only 13,569 households were randomly selected and were interviewed in the INA. This particular study used only data from INA relative to adults (20-59 years) residing in urban areas, excluding pregnant women, with a sample of 16,638 individuals.

\section{Instruments and measures}

Food consumption in INA was measured through self-reporting in two intake records on nonconsecutive days. Participants were instructed on how to annotate household measures, in addition to fill out the times and source of food consumed at mealtime (at home or away from home), and a detailed description of all foods and beverages consumed; including the method of preparation, ingredients and brands.

Quality control in the dietary data collection was performed by trained interviewers, who reviewed the information contained in food records in order to detect faults in annotations and made 
the necessary corrections. Items commonly omitted, such as candies and sweets in general, as well as beverages such as coffee and soda, had their consumption investigated by the interviewer.

\section{Procedures}

For this study, lunch was defined as the food event with the highest energy content that occurred between 11:00a.m. and 3:00p.m. When there was more than one food consumption episode reported within this time interval, the one with the highest energy contribution was considered, and the smaller values were disregarded. In order to consider the place of the meal in the analysis, only data of the first food record were considered in this study. However, once individual questionnaires were obtained for every day of the week and throughout all four seasons of the year, mean usual intake among the population could be estimated ${ }^{13}$. In this way, the final sample consisted of 16,096 adults who had at least one food consumption episode during this time slot.

To evaluate the quality of lunch, the main meal quality index (MMQI) was applied 14. The MMQI consists of 10 items, of equal weight, which together result in a score between zero to 100 points: fruits; vegetables (except potatoes); carbohydrates; total fat; saturated fat; animal protein/total protein ratio; fibers; processed meats; desserts and sugary drinks; and energy density (Table 1). The higher the score indicator, the better is the quality of the meal, intermediate values were given a score proportional to the amount consumed 14. The MMQI cut-off points for the maximum, intermediate, and minimum scores were based on a proportion of the daily recommendations proposed by the World Health Organization (WHO) and the World Cancer Research Fund (WCRF), which considers that a main meal should provide at least $30 \%$ of the daily intake. The MMQI internal validity and reliability were evaluated previously in two distinguished populations: Brazil 9,15 and the United Kingdom 14.

The demographic variables analyzed were gender (male and female) and age groups (20-39 years and 40-59 years). Socioeconomic variables analyzed were education (up to 2 years, 3-8 years and more than 8 years of schooling completed) and income (up to 1 minimum wage - MW - per capita, 2 or more MW per capita). In addition, the source of food consumed at meal (at home or away from home) was considered, as was the energy value of the meal (in Kcal) as adjustment variables.

\section{Data analysis}

Statistical analysis was performed using the "survey" module of the Stata software, version 13 (StataCorp LP, College Station, USA), considering the sample design and a significance level of 5\%. The quality of lunch was described by median, mean, standard error and $95 \%$ confidence interval (95\%CI) for the mean for the final scores and for each item. To assess the adjusted association coefficients linear regression models stratified by the Brazilian region were performed (North, Northeast, South, Southeast and Central). The selection of explanatory variables for multiple models was based on plausibility and statistical adjustment, observing p-values $<0.200$ (stepwise forward). Additionally, mean scores of MMQI, for each Brazilian region, were adjusted by gender, age, education and per capita income (residuals method).

\section{Results}

Regarding the population studied, 52\% were female, 60\% aged between 19 and 39 years, 55\% studied eight complete years or more, $35 \%$ had per capita incomes of up to $1 \mathrm{MW}$ and $25 \%$ reported having lunch composed of food sourced away from home in the first record. In general, the quality of the Brazilians lunch was higher for men, older, with low education (3 years or less and 3-8 years), to those with lower per capita incomes ( 1 or less MW and 1-2 MW), to those that stated "home" as the source of food consumed, and to those which lunch had energy content between 640 to $880 \mathrm{Kcal}$ (Table 2).

The average energy consumption at lunch was $704 \mathrm{Kcal}$ (standard deviation $-\mathrm{SD}=300$ ), that corresponds to $41 \%$ of the total energy consumed during the day, and the mean score of the quality of the meal was 57 points (standard error $-\mathrm{SE}=0.30$ ), with a median of 60 points (Table 3 ). Considering the lunch definition criteria used, the food groups that most prevalent in the meal compositions 
Main mean quality index (MMQI) components and score criteria.

\begin{tabular}{lccc}
\hline Component & Recomendation * & \multicolumn{2}{c}{ Score range ** } \\
& & 0 point & 10 points \\
\hline Fruit & $400 \mathrm{~g}$ of fruits and vegetables per day & $0 \mathrm{~g}$ & $\geq 80 \mathrm{~g}$ \\
Vegetables (excluding potato) & $400 \mathrm{~g}$ of fruits and vegetables per day & $\leq 80 \mathrm{~g}$ & $\geq 160 \mathrm{~g}$ \\
Animal protein/Total protein & 1 portion/day of vegetable protein & $100 \%$ & $\leq 80 \%$ \\
Fiber & $25 \mathrm{~g}$ per day & $\leq 7 \mathrm{~g}$ & $\geq 10 \mathrm{~g}$ \\
Carbohydrate & $55-75 \%$ of total energy & $\leq 40 \%$ & $\geq 55 \%$ \\
Total fat & $15-30 \%$ of total energy & $\geq 40 \%$ & $\leq 30 \%$ \\
Saturated fat & $<10 \%$ of total energy & $\geq 13 \%$ & $\leq 10 \%$ \\
Processed meat & Avoid & $\geq 1$ portion & 0 portion \\
Desserts and sugary drinks & Avoid & $\geq 1$ portion & 0 portion \\
Energy density & $\leq 1.25 \mathrm{Kcal} / \mathrm{g}$ & $\geq 1.65 \mathrm{Kcal} / \mathrm{g}$ & $\leq 1.25 \mathrm{Kcal} / \mathrm{g}$ \\
\hline
\end{tabular}

Note: the MMQI is comprised of 10 components of equal weight, which together result in a score between 0 and 100 points (inclusive). The higher the score indicator, the better the quality of the meal.

* World Health Organization, 2003; World Cancer Research Fund, 2007;

** For intermediate values a score proportional to the amount consumed was given.

were: rice (19\%), legumes (16\%), vegetables (11\%), soft drinks (9\%), meats (7\%), fruit juice (6\%), potatoes (5\%), pasta (4\%), fruits (4\%), coffee (3\%), eggs (2\%), sugary desserts (2\%), sandwich and snacks (2\%) and others (10\%).

Although no difference was observed in the final score between regions, some components had significant difference (Figure 1). Considering the components of the score, the lowest values were observed for the items "fruits" and "vegetables", with means below 1 point. The highest scores were observed for "desserts and sugary drinks" and "processed meats', averaging around nine points each. The North region had the best score for the component "fruit" and the worst score for "energy density", while the Northeast had the worst score for "vegetables". The Central was the region with the highest score for "vegetables" and the South had the lowest fiber intake. The Southeast region had intermediate score values for almost all components (Figure 1).

All variables analyzed with the quality of lunch, by regions, both in the bivariate models as well as in the multiple regression models, were described in Table 4. the North and Northeast lunch qualities were associated with gender and education, and the Central lunch quality was associated with age, while the South lunch quality was associated with gender, age and income and the Southeast lunch quality was associated with gender, age, education and income. Education and income levels showed low Pearson coefficient correlation in all regions, the highest value found was 0.18 in Northeast.

Higher per capita income ( $\geq 3 \mathrm{MW}$ compared to $\leq 1 \mathrm{MW}$ ) was associated with a worse lunch quality in the South and in the Southeast (1-2 MW and 3 or more MW). Brazilians in the 40-59 years old group had a higher quality lunch in the Central, South and Southeast. In relation to 3 or less years of education, in the North, people with 3-8 years of education had a higher MMQI score, in comparison to other years. In contrast, in the Northeast and Southeast, individuals with 8 or more years of education had a smaller MMQI score. Men had a better quality lunch in the North, Northeast, South and Southeast.

After adjustment for gender, age, education and per capita income, differences of the MMQI mean score between the regions were observed (Table 4). The North had the worst lunch quality, 56 points on average, while the Central had the best lunch quality, around 59 points. 
Table 2

Characteristics of the population studied and lunch meal quality. Brazil, 2008-2009.

\begin{tabular}{|c|c|c|c|c|c|c|}
\hline \multirow[t]{2}{*}{ Variables } & \multicolumn{2}{|c|}{ Individuals } & \multicolumn{4}{|c|}{ Meal quality } \\
\hline & $\mathbf{n}$ & $\%$ * & Median & Mean * & SE & $95 \% \mathrm{Cl}$ \\
\hline \multicolumn{7}{|l|}{ Demographic } \\
\hline \multicolumn{7}{|l|}{ Gender } \\
\hline Male & 7,098 & 47.80 & 61.03 & 58.41 & 0.41 & $58.30 ; 59.50$ \\
\hline female & 8,998 & 52.20 & 58.79 & 56.73 & 0.35 & $56.37 ; 57.08$ \\
\hline \multicolumn{7}{|l|}{ Age (years) } \\
\hline $19-39$ & 9,905 & 60.48 & 59.81 & 57.23 & 0.35 & $56.89 ; 57.56$ \\
\hline $40-59$ & 6,101 & 39.52 & 60.22 & 58.45 & 0.43 & $58.01 ; 58.88$ \\
\hline \multicolumn{7}{|l|}{ Socioeconomic } \\
\hline \multicolumn{7}{|l|}{ Education (years) } \\
\hline 3 or less & 1,812 & 8.60 & 60.84 & 58.85 & 0.38 & $58.09 ; 59.60$ \\
\hline $3-8$ & 5,940 & 36.69 & 60.57 & 58.53 & 0.22 & $58.10 ; 58.96$ \\
\hline 8 or more & 8,344 & 54.70 & 58.85 & 56.84 & 0.19 & $56.46 ; 57.21$ \\
\hline \multicolumn{7}{|c|}{ Per capita income (MW) } \\
\hline 1 or less & 6,994 & 34.86 & 60.07 & 58.20 & 0.20 & $57.81 ; 58.59$ \\
\hline $1-2$ & 4,489 & 29.20 & 60.00 & 57.80 & 0.25 & $57.31 ; 58.30$ \\
\hline 3 or more & 4,613 & 35.94 & 58.76 & 56.79 & 0.26 & $56.27 ; 57.31$ \\
\hline \multicolumn{7}{|l|}{ Dietary intake } \\
\hline \multicolumn{7}{|c|}{ Source of food consumed at meal } \\
\hline At home & 12,645 & 75.03 & 60.00 & 58.21 & 0.15 & $57.91 ; 58.51$ \\
\hline Away from home & 3,451 & 24.97 & 57.72 & 55.77 & 0.29 & $55.19 ; 56.34$ \\
\hline \multicolumn{7}{|l|}{ Energy (Kcal) } \\
\hline$<640$ & 3,697 & 24.31 & 57.37 & 55.26 & 0.26 & $54.74 ; 55.78$ \\
\hline $640-880$ & 10,699 & 65.81 & 60.52 & 58.67 & 0.17 & $58.35 ; 59.00$ \\
\hline$>880$ & 1,700 & 9.88 & 59.97 & 56.75 & 0.44 & $55.89 ; 57.62$ \\
\hline \multicolumn{7}{|l|}{ Regions } \\
\hline North & 2,303 & 14.31 & 58.31 & 56.45 & 0.66 & $55.16 ; 57.75$ \\
\hline Northeast & 5,832 & 36.23 & 60.00 & 57.92 & 0.44 & $57.06 ; 58.79$ \\
\hline Central & 2,290 & 14.23 & 60.93 & 58.54 & 0.69 & $57.18 ; 59.90$ \\
\hline South & 2,033 & 12.63 & 60.00 & 56.78 & 0.67 & $55.46 ; 58.09$ \\
\hline Southeast & 3,638 & 22.60 & 60.33 & 57.03 & 0.54 & $55.95 ; 58.10$ \\
\hline
\end{tabular}

95\% Cl: 95\% confidence interval; MW: minimum wage; SE: standard error.

* Considering the sample design.

\section{Discussion}

In this study, the mean quality of lunch consumed by Brazilians, measured by the MMQI index, scored 57 points out of 100, indicating a poor nutritional quality. It was observed that lunch was characterized by low consumption of fruits and vegetables, corroborating other studies 16,17 . At least $50 \%$ of the studied population, in all regions, did not consume any portion of fruit or vegetable at lunch. Only in the North, Central and South regions, the mean scores were higher than one point for the components "fruit" and "vegetable", respectively. In this nationally representative data an average of 54Kcal was derived from daily fruit intake, which represents less than a portion (70Kcal) ${ }^{18}$. According to Malta et al. 18 , the Central and Southeast are the Brazilian regions with the highest daily consumption of fruits and vegetables, followed, in decreasing order, by the North, South and finally the Northeast 18 . However, the same study claims the Central and Southeast to be the regions with the largest consumption of soft drinks, followed, in decreasing order, by the South, North and Northeast 19. 
Table 3

Meal quality and main mean quality index (MMQI) components score. Brazil, 2008-2009.

\begin{tabular}{lcccccc}
\hline & Mean & SE & $\mathbf{9 5 \% C l}$ & P25 & P50 & P75 \\
\hline Fruits & 0.69 & 0.02 & $0.61 ; 0.77$ & 0.00 & 0.00 & 0.00 \\
Vegetables & 0.79 & 0.02 & $0.72 ; 0.87$ & 0.00 & 0.00 & 0.00 \\
Carbohydrates & 5.49 & 0.03 & $5.32 ; 5.63$ & 0.00 & 5.93 & 10.00 \\
Total fat & 7.69 & 0.03 & $7.58 ; 7.80$ & 6.21 & 10.00 & 10.00 \\
Satured fat & 7.90 & 0.03 & $7.79 ; 8.02$ & 8.04 & 10.00 & 10.00 \\
Animal protein/Total protein & 6.29 & 0.04 & $6.14 ; 6.44$ & 0.00 & 10.00 & 10.00 \\
Fiber & 4.78 & 0.04 & $4.63 ; 4.92$ & 0.00 & 4.17 & 10.00 \\
Processed meat & 9.59 & 0.01 & $9.53 ; 9.66$ & 10.00 & 10.00 & 10.00 \\
Desserts and sugary drinks & 8.68 & 0.02 & $8.58 ; 8.78$ & 10.00 & 10.00 & 10.00 \\
Energy density & 5.36 & 0.03 & $5.23 ; 5.48$ & 0.00 & 5.70 & 10.00 \\
Meal quality & 57.28 & 0.30 & $56.68 ; 57.87$ & 46.64 & 60.00 & 70.00 \\
\hline
\end{tabular}

95\% Cl: 95\% confidence interval; SE: standard error.

\section{Figure 1}

Average score and 95\% confidence interval $(95 \% \mathrm{Cl})$ of the main meal quality index (MMQI) components by Brazilian regions, $2008-2009$.

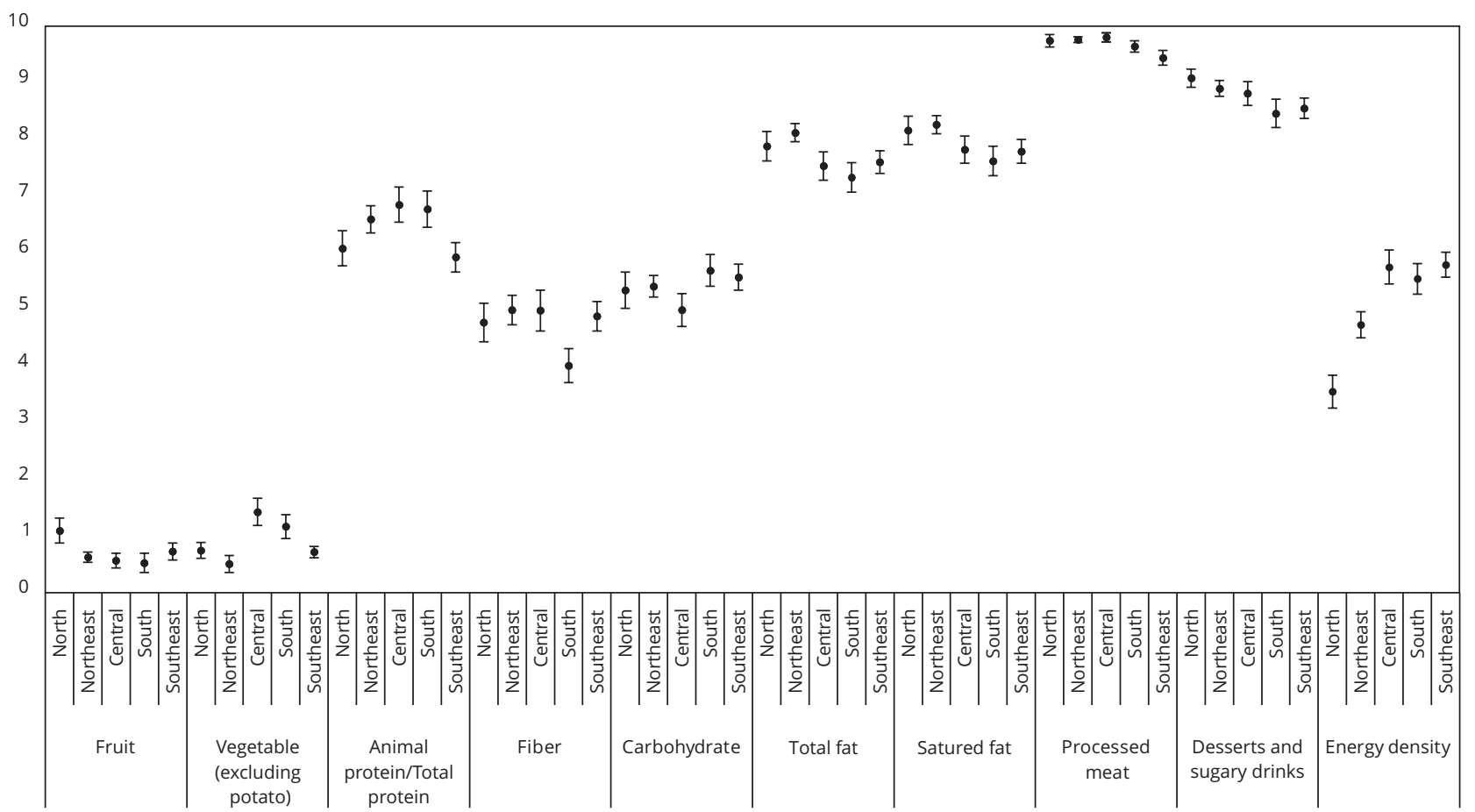


Table 4

Lunch quality and associated factors. Brazil, 2008-2009.

\begin{tabular}{|c|c|c|c|c|c|c|c|c|}
\hline & \multicolumn{4}{|c|}{ Bivariate models } & \multicolumn{4}{|c|}{ Mutiple model } \\
\hline & Coeficient & SE & $95 \% \mathrm{Cl}$ & p-value * & Coeficient & SE & $95 \% \mathrm{Cl}$ & p-value * \\
\hline \multicolumn{9}{|c|}{ North $(56.23$ points; $\mathrm{SE}=0.07 ; 95 \% \mathrm{Cl}: 56.13 ; 56.33)$ ** } \\
\hline Gender male (ref. female) & 2.57 & 0.69 & $1.21 ; 3.93$ & $<0.001$ & 1.61 & 0.73 & $0.19 ; 3.04$ & 0.03 \\
\hline Age $40-59$ years (ref. 20-39) & 0.00 & 0.03 & $-0.07 ; 0.06$ & 0.89 & - & - & - & - \\
\hline \multicolumn{9}{|l|}{ Education (ref. 3 or less years) } \\
\hline $3-8$ & 1.54 & 0.74 & $0.08 ; 2.99$ & 0.04 & 2.34 & 1.19 & $0.00 ; 4.68$ & 0.05 \\
\hline 8 or more & -0.71 & 0.70 & $-2.09 ; 0.66$ & 0.31 & 1.12 & 1.13 & $-1.10 ; 3.33$ & 0.32 \\
\hline \multicolumn{9}{|c|}{ Per capita income (ref. $\leq 1 \mathrm{MW}$ ) } \\
\hline $1-2$ & 0.23 & 0.79 & $-1.31 ; 1.78$ & 0.77 & - & - & - & - \\
\hline 3 or more & 0.11 & 0.80 & $-1.45 ; 1.67$ & 0.89 & - & - & - & - \\
\hline \multicolumn{9}{|c|}{ Northeast $(57.90$ points; $\mathrm{SE}=0.05 ; 95 \% \mathrm{Cl}: 57.85 ; 57.96)$ ** } \\
\hline Gender male (ref. female) & 2.70 & 0.43 & $1.85 ; 3.55$ & $<0.001$ & 2.12 & 0.45 & $1.23 ; 3.01$ & $<0.001$ \\
\hline Age $40-59$ years (ref. 20-39) & 0.04 & 0.02 & $0.00 ; 0.08$ & 0.06 & 0.03 & 0.02 & $-0.01 ; 0.07$ & 0.17 \\
\hline \multicolumn{9}{|l|}{ Education (ref. 3 or less years) } \\
\hline $3-8$ & 0.49 & 0.45 & $-0.39 ; 1.36$ & 0.28 & -0.61 & 0.63 & $-1.84 ; 0.62$ & 0.33 \\
\hline 8 or more & -1.21 & 0.43 & $-2.05 ;-0.36$ & 0.01 & -1.28 & 0.61 & $-2.47 ;-0.08$ & 0.04 \\
\hline \multicolumn{9}{|c|}{ Per capita income (ref. $\leq 1 \mathrm{MW}$ ) } \\
\hline $1-2$ & -0.37 & 0.51 & $-1.37 ; 0.62$ & 0.46 & - & - & - & - \\
\hline 3 or more & -0.43 & 0.58 & $-1.56 ; 0.71$ & 0.46 & - & - & - & - \\
\hline \multicolumn{9}{|c|}{ Central $(58.81$ points; $\mathrm{SE}=\mathbf{0 . 0 5} ; \mathbf{9 5} \% \mathrm{Cl}: 58.74 ; 58.89)$ ** } \\
\hline Gender male (ref. female) & 0.50 & 0.73 & $-0.93 ; 1.93$ & 0.50 & - & - & - & - \\
\hline Age $40-59$ years (ref. 20-39) & 0.10 & 0.03 & $0.04 ; 0.17$ & $<0.001$ & 0.09 & 0.03 & $0.02 ; 0.16$ & 0.01 \\
\hline \multicolumn{9}{|l|}{ Education (ref. 3 or less years) } \\
\hline $3-8$ & 1.54 & 0.74 & $0.09 ; 3.00$ & 0.04 & 1.66 & 1.44 & $-1.17 ; 4.49$ & 0.25 \\
\hline 8 or more & -1.48 & 0.72 & $-2.90 ;-0.06$ & 0.04 & 0.57 & 1.45 & $-2.28 ; 3.42$ & 0.69 \\
\hline \multicolumn{9}{|c|}{ Per capita income (ref. $\leq 1 \mathrm{MW}$ ) } \\
\hline $1-2$ & -0.70 & 0.79 & $-2.25 ; 0.84$ & 0.37 & - & - & - & - \\
\hline 3 or more & -0.58 & 0.75 & $-2.05 ; 0.90$ & 0.44 & - & - & - & - \\
\hline \multicolumn{9}{|c|}{ South $(56.61$ points; $\mathrm{SE}=0.11 ; 95 \% \mathrm{Cl}: 56.48 ; 56.74) * *$} \\
\hline Gender male (ref. female) & 1.71 & 0.82 & $0.11 ; 3.31$ & 0.04 & 2.72 & 0.85 & $1.05 ; 4.39$ & $<0.001$ \\
\hline Age 40-59 years (ref. 20-39) & 0.11 & 0.04 & $0.04 ; 0.18$ & $<0.001$ & 0.08 & 0.04 & $0.00 ; 0.16$ & 0.04 \\
\hline \multicolumn{9}{|l|}{ Education (ref. 3 or less years) } \\
\hline $3-8$ & 2.63 & 0.84 & $0.98 ; 4.28$ & $<0.001$ & -0.39 & 1.79 & $-3.90 ; 3.11$ & 0.83 \\
\hline 8 or more & -3.15 & 0.82 & $-4.76 ;-1.55$ & $<0.001$ & -1.82 & 1.86 & $-5.47 ; 1.82$ & 0.33 \\
\hline \multicolumn{9}{|c|}{ Per capita Income (ref. $\leq 1 \mathrm{MW}$ ) } \\
\hline $1-2 \mathrm{MW}$ & 2.93 & 0.87 & $1.23 ; 4.63$ & $<0.001$ & 1.44 & 1.11 & $-0.74 ; 3.61$ & 0.20 \\
\hline 3 or more MW & -3.51 & 0.82 & $-5.11 ;-1.90$ & $<0.001$ & -2.17 & 1.13 & $-4.38 ; 0.04$ & 0.05 \\
\hline \multicolumn{9}{|c|}{ Southeast $(58.16$ points; $\mathrm{SE}=0.06 ; 95 \% \mathrm{Cl}: 58.08 ; 58.24)$ ** } \\
\hline Gender male (ref. female) & 2.53 & 0.59 & $1.37 ; 3.69$ & $<0.001$ & 2.85 & 0.62 & $1.63 ; 4.07$ & $<0.001$ \\
\hline Age $40-59$ years (ref. 20-39) & 0.09 & 0.03 & $0.04 ; 0.14$ & 0.00 & 0.07 & 0.03 & $0.02 ; 0.13$ & 0.01 \\
\hline \multicolumn{9}{|l|}{ Education (ref. 3 or less years) } \\
\hline $3-8$ & 1.45 & 0.60 & $0.27 ; 2.63$ & 0.02 & -2.17 & 1.19 & $-4.52 ; 0.17$ & 0.07 \\
\hline 8 or more & -2.51 & 0.59 & $-3.67 ;-1.36$ & $<0.001$ & -2.84 & 1.26 & $-5.30 ;-0.37$ & 0.02 \\
\hline \multicolumn{9}{|l|}{ Per capita income (ref. $\leq 1 \mathrm{MW}$ ) } \\
\hline $1-2$ & -0.22 & 0.63 & $-1.45 ; 1.02$ & 0.73 & -1.65 & 0.75 & $-3.13 ;-0.17$ & 0.03 \\
\hline 3 or more & -2.06 & 0.61 & $-3.25 ;-0.86$ & 0.00 & -2.53 & 0.79 & $-4.09 ;-0.98$ & 0.00 \\
\hline
\end{tabular}

95\% Cl: 95\% confidence interval; MW: minimum wage; ref.: reference; SE: standard error.

* Wald test;

** Mean adjusted by gender, age, education, per capita income and meal energy. 
As expected, there are differences in the lunches consumed by adults between Brazilian regions, with distinctions in its relationships with demographic and socioeconomic factors. In the North and Northeast a better lunch quality was observed for males, and in the Central a better lunch quality was observed for people aged 40 years or more; while in the South and Southeast a better lunch quality was observed for males and people aged 40 years or more. Older adults consume more fruits, vegetables, fish, and meats containing less fat, soft drinks, and sugary foods 16,20; and, compared to women, males usually eat beans on a more regular basis 16,20. Besides this, in Brazil, although women had consumed more fruits and vegetables, they also consumed less carbohydrates and fiber, and more sugary foods 16,20 .

Higher levels of income and education were associated with worse lunch quality in the Southeast, and in the South worse lunch qualities were associated only with income. In agreement with this, the Brazilian National Health Survey (PNS) results showed that Brazilians with higher education levels have a higher consumption of sugary foods and added salt, with a lower consumption of beans 16,21. Furthermore, Popkin et al. 21 observed an increase in obesity rates for individuals, with higher incomes, living in the urban area of developing countries 22,23,24. Economic growth and technological development potentially result in a more caloric, palatable, inexpensive and ready-to-eat food consumption, leading the population to an excessive dietary intake 12,14,25.

The choice of foods that are consumed in the same meal occurs in a very complex way, being modulated by several determinants, such as sociodemographic conditions, gender, age, nutritional status, place of consumption, food preparation, and cultural habits 6,7,8. Moreover, the meal quality was associated with its place of preparation and consumption. Bandoni et al. 25 found that, when compared to meals eaten at home, meals consumed in commercial restaurants presented higher levels of sugar and fat 26. In fact, Gorgulho et al. 26, evaluating the nutritional quality of main meals consumed by the residents of São Paulo, the largest Brazilian city, found that main meals consumed by adolescents, adults and the elderly were not nutritionally adequate, especially when they were consumed away from home.

Although Brazilians are still preparing their own meals 27, a decrease in acquisition of traditional Brazilian foods and an increase in consumption of fast foods is observed 12,28,29. Between 2003 and 2008, the acquisitions of rice and beans were reduced by $40 \%$ and by $26 \%$, respectively; while the acquisition of ready-to-eat preparations and cola drinks were increased by $37 \%$ and by $39 \%$, respectively 12 . In this way, aimed to prevent population weight gain and to educate individuals for a healthier diet, in 2014, the Brazilian Ministry of Health published the new Food Guide for the Brazilian Population; it is the first food guide with guidelines aimed at meals, for both the individual and the collective 27. The new guide recommends moderation in the use of food products that are sold ready for consumption, and encourages the consumption of fresher foods, such as fruits and vegetables 28.

In our study, most adults did not consume processed meats, desserts and sugary drinks during lunch. However, Santos et al. 4, studying the lunch of adults living in São Paulo, described that, among the five patterns identified, three of them (sweetened juices, Western and meat) were characterized by foods that are high in sugar, fat and sodium and low in fiber content. As described in literature, it was observed that lunches away from home were of lower quality than lunches at home 26,30. Bezerra et al. 29, comparing daily food consumption at home and away from home, showed that about 40-60\% of the energy from alcohol, soft drinks, snacks, sandwiches and pizzas were consumed away from home 18 .

The MMQI allows the evaluation of the meals overall qualities, classifying them into categories that facilitate the interpretation of the results. The indicator was created to reflect the complexity of dietary patterns, in a way that a high score in a single component does not imply in a high overall, final score. Moreover, the MMQI was previously validated for use in this population, and in the analyses with macro- and micro-nutrients, positive associations with nutrients considered protective for noncommunicable diseases were verified, as were negative associations with nutrients described as risk factors 9,14 . 


\section{Limitations}

Our study has limitations, and one of these is the use of a single food record. Although the INA has collected two food records, work with only the first record allowed us to adjust the model for the source of food consumed at mealtime (at home or away from home), which has been described in literature as a meal quality determinant 30,31 . In addition, another limitation was to not distinguish the place of consumption of meals eaten away from home in the workplace, school or business. Carus et al. 31 showed that in the southeast of Brazil, about $60 \%$ of meals eaten away from home occur in the workplace; and compared to the meals eaten at home, institutional meals present a lower energy density and a higher fiber content 26 . Yet, the lunch definition by time period (between 11:00a.m. and 3:00p.m.) could also have included some other food event. However, the analysis of lunch components using this definition showed foods typically consumed during Brazilian's lunch.

Finally, the rural areas were not considered. It is recognized that residents of rural areas tend to have a different diet with an increased consumption of beans, meat and dairy products, and lower consumption of ultra-processed foods, sugary beverages and candies, with a higher energy density 12,16,20. In addition, work routine and the environment are different between urban and rural areas, which could affect meals prepared at work and away from home.

\section{Implications for research and practice}

One of the principles of the Brazilian National Food and Nutrition Policy (PNAN) is about food and nutritional safety with sovereignty, which is based on everyone's right to quality food, being based on eating practices that promote health and respect cultural diversity and that are environmentally, culturally, economically and socially sustainable. To achieve this national goal it is of paramount importance to public health to know the food habits and the sociodemographic differences between Brazilian regions.

In summary, despite the moderate consumption of sugars and fats, the consumption of foods rich in fiber and vitamins, such as fruits and vegetables, were low; with observed differences between the lunches consumed in the regions, with distinctions in its nutritional quality and in its relationships with demographic and socioeconomic factors. North and Northeast lunch qualities were associated with gender and in the Central with age, while the South and Southeast lunch qualities were associated with gender, age, education and income. Thus, public policies that not only encourage but also provide access and more conditions of acquisition of fruits and vegetables and promote healthy food systems, including nutrition education and the empowerment of individuals, have clearly shown to be necessary.

\section{Contributors}

B. M. Gorgulho, R. de Oliveira Santos, J. A. Teixeira, V. T. Baltar and D. M. Marchioni contributed towards study concepts and design, and towards data analysis and interpretation, writing in the article and approved the final version.

\section{Acknowledgments}

This study was supported by the Brazilian National Research Council (grant number 142341/2013-4) and by the São Paulo Research Foundation (grant number 2014/19355-6).

\section{References}

1. Leech RM, Worsley A, Timperio A, McNaughton SA. Understanding meal patterns: definitions, methodology and impact on nutrient intake and diet quality. Nutr Res Rev 2015; 28:1-21.

2. Hoffmann I. Transcending reductionism in nutrition research. Am J Clin Nutr 2003; 78(3 Suppl):514S-6.

3. Meiselman HL. Dimensions of the meal. Journal of Foodservice Banner 2008; 19:13-21.

4. de Oliveira Santos R, Fisberg RM, Marchioni DM, Troncoso Baltar V. Dietary patterns for meals of Brazilian adults. Br J Nutr 2015; 114:822-8 
5. Monfort-Pires M, Ferreira SRG. Modification in a single meal is suficiente to provoke benefits in inflammatory responses of individuals at low-to-moderate cardiometabolic risk. Clin Nutr 2016; 35:1242-50.

6. Wang WC, Worsley A, Hodgson V. Classification of main meal patterns - a latent class approach. Br J Nutr 2013; 109:2285-96.

7. Costa AIA, Schoolmeester D, Dekker M, Jongen WMF. To cook or not to cook: a meansend study of motives for choice of meal solutions. Food Qual Prefer 2007; 18:77-88.

8. Fjellström K. Mealtime and meal patterns from a cultural perspective. Food Nutr Res 2008; 48:161-4.

9. Gorgulho BM, Pot GK, Sarti FM, Marchioni DM. Main meal quality in Brazil and United Kingdom: similarities and differences. Appetite 2017; 111:151-7.

10. Barros MBA, Francisco PMSB, Zanchetta LM, César CLG. Tendências das desigualdades sociais e demográficas na prevalência de doenças crônicas no Brasil, PNAD: 2003-2008. Ciênc Saúde Coletiva 2011; 16:3755-68.

11. Departamento de Atenção Básica, Secretaria de Atenção à Saúde, Ministério da Saúde. Política Nacional de Alimentação e Nutrição. Brasília: Ministério da Saúde; 2013.

12. Instituto Brasileiro de Geografia e Estatística. Pesquisa de Orçamentos Familiares 20082009: análise do consumo alimentar pessoal no Brasil. Rio de Janeiro: Instituto Brasileiro de Geografia e Estatística; 2011.

13. Guenther PM, Reedy J, Krebs-Smith SM, Reeve BB, Basiotis PP. Development and evaluation of the healthy eating index-2005: technical report. Washington DC: Center for $\mathrm{Nu}-$ trition Policy and Promotion, U.S. Department of Agriculture; 2007.

14. Gorgulho B, Pot GK, Sarti FM, Fisberg RM, Marchioni DM. Measuring quality of meals: Development of an index to be used in multicultural context. Ann Nutr Metab 2015; 67:235-6.

15. Jaime PC, Stopa SR, Oliveira TP, Vieira ML, Szwarcwald CL, Malta DC. Prevalência e distribuição sociodemográfica de marcadores de alimentação saudável, Pesquisa Nacional de Saúde, Brasil 2013. Epidemiol Serv Saúde 2015; 24:267-76.

16. Bigio RS, Verly-Jr. E, Castro MA, César CLG, Fisberg RM, Marchioni DML. Determinantes do consumo de frutas e hortaliças em adolescentes por regressão quantílica. Rev Saúde Pública 2011; 45:448-56.

17. Bezerra IN, Moura Souza A, Pereira RA, Sichieri R. Contribution of foods consumed away from home to energy intake in Brazilian urban areas: the 2008-9 Nationwide Dietary Survey. Br J Nutr 2013; 109:1276-83.

18. Malta DC, Andrade SSCA, Stopa SR, Pereira CA, Szwarcwald CL, Silva Júnior JB, et al. Estilos de vida da população brasileira: Pesquisa Nacional de Saúde, Brasil 2013. Epidemiol Serv Saúde 2015; 24:217-26.
19. Claro RM, Santos MAS, Oliveira TP, Pereira CA, Szwarwald CL, Malta DC. Consumo de alimentos não saudáveis relacionados a doenças crônicas não transmissíveis no Brasil: Pesquisa Nacional de Saúde, Brasil 2013. Epidemiol Serv Saúde 2015; 24:257-65.

20. Oliveira MM, Malta DC, Santos MAS, Oliveira TP, Nilson EAF, Claro RM. Consumo elevado de sal autorreferido em adultos: Pesquisa Nacional de Saúde, Brasil 2013. Epidemiol Serv Saúde 2015; 24:249-56.

21. Popkin BM, Adair LS, Ng SW. Global nutrition transition and the pandemic of obesity in developing countries. Nutr Rev 2012; 70:3-21.

22. Cutler D, Glaeser E, Shapiro J. Why have Americans become more obese? Cambridge: National Bureau of Economic Research; 2003. (Working Paper, 9446).

23. Finkelstein EA, Ruhm CJ, Kosa KM. Economic causes and consequences of obesity. Annu Rev Public Health 2005; 26:239-57.

24. Philipson TJ, Posner RA. The long-run growth in obesity as a function of technological change. Cambridge: National Bureau of Economic Research; 1999. (Working Paper, 7423).

25. Bandoni DH, Canella DS, Levy RB, Jaime PC. Eating out or in from home: analyzing the quality of meal according eating locations. Rev Nutr 2013; 26:625-32.

26. Gorgulho BM, Fisberg RM, Marchioni DML. Nutritional quality of major meals consumed away from home in Brazil and its association with the overall diet quality. Prev Med 2013; 57:98-101.

27. Departamento de Atenção Básica, Secretaria de Atenção à Saúde, Ministério da Saúde. Guia alimentar para a população brasileira. Brasília: Ministério da Saúde; 2014.

28. Souza AM, Pereira RA, Yokoo EM, Levy RB, Sichieri R. Most consumed foods in Brazil: National Dietary Survey 2008-2009. Rev Saúde Pública 2003; 47 Suppl 1:190s-9.

29. Bezerra IN, Sichieri R. Eating out of home and obesity: a Brazilian nationwide survey. Public Health Nutr 2009; 12:2037-43.

30. Moubarac JC, Claro RM, Baraldi LG, Levy RB, Martins AP, Cannon G, et al. International differences in cost and consumption of readyto-consume food and drink products: United Kingdom and Brazil, 2008-2009. Glob Public Health 2013; 8:845-56.

31. Carus JP, França GV, Barros AJD. Place and type of meals consumed by adults in medium sized cities. Rev Saúde Pública 2014; 41:68-74. 


\section{Resumo}

O estudo teve como objetivo avaliar a qualidade do almoço consumido por adultos brasileiros e os determinantes sociodemográficos em cada macrorregião brasileira, com delineamento transversal e uma amostra representativa das populações regionais. A amostra incluiu 16.096 adultos, participantes do Inquérito Nacional de Alimentação, um componente da Pesquisa de Orçamentos Familiares. A qualidade do almoço foi avaliada através do main meal quality index (MMQI), com 10 itens de pesos iguais que resultaram em um escore que variava entre zero e 100 pontos. Nas análises, modelos de regressão linear mediram a associação entre a qualidade do almoço e fatores sociodemográficos. O consumo energético médio no almoço foi $704 \mathrm{Kcal}(\mathrm{DP}=300)$, e o escore médio da qualidade do almoço foi 57 pontos $(D P=0,30)$. A Região Norte teve o pior MMQI (56 pontos, $D P=0,07)$, enquanto o Centro-oeste teve o melhor $M M Q I$ ajustado (59 pontos, DP = 0,05). O escore final do MMQI mostrou associação positiva com o gênero masculino e idade de 20-39 anos, e associação negativa com escolaridade de oito anos ou mais, renda per capita de pelo menos três salários mínimos e consumo de refeições preparadas fora de casa. Apesar das diferenças entre fatores sociodemográficos, em todas a macrorregiões brasileiras os adultos consumiam um almoço rico em alimentos com alto teor de açúcar e gordura e com porções insuficientes de frutas e verduras, resultando em um almoço de baixa qualidade alimentar.

Almoço; Comportamento Alimentar; Refeições; Indicadores Demográficos

\section{Resumen}

El objetivo de este estudio fue evaluar la calidad del almuerzo que consumen los adultos en Brasil $y$ sus determinantes sociodemográficos en cada región brasileña. Se trata de un estudio transversal con una muestra representativa de las poblaciones regionales. La muestra comprendió a 16.096 adultos de la Encuesta Nacional sobre Dieta, Encuesta sobre Presupuestos Familiares en Brasil. La calidad del almuerzo fue evaluada aplicando el main meal quality index (MMQI), que comprendia 10 items de pesos equivalentes que resultaron en un marcador que abarcaba de cero a 100 puntos. El análisis se realizó mediante modelos de regresión lineal que midieron la asociación entre el almuerzo de calidad y sus factores sociodemográficos. El promedio de consumo de calorías en el almuerzo fue $704 \mathrm{Kcal}(S D=300), y$ la media del índice de calidad de la comida fue 57 puntos $(S E=0,30)$. La región Norte tuvo el peor indice de MMQI (56 puntos, $S E=0,07$ ), mientras que el Centro-oeste tuvo el mejor índice de MMQI ajustado (59 puntos, $S E=0,05$ ). El indice final de MMQI se asoció positivamente al género masculino y edades comprendidas entre los 20-39 años, y fue inversamente asociado con contar con ocho años o más de educación, unos ingresos per cápita de al menos tres salarios mínimos, y un consumo de comidas preparadas fuera de casa. A pesar de las diferencias entre los factores sociodemográficos, todas las regiones brasileñas contaron con un almuerzo compuesto por comidas ricas en azúcares $y$ grasas, con insuficiente porciones de frutas y verduras, constituyendo una comida de baja calidad.

Almuerzo; Conducta Alimentaria; Comidas;

Indicadores Demográficos
Submitted on 21/Apr/2017

Final version resubmitted on 11/Sep/2017

Approved on 02/Oct/2017 